Mattison Hale

Boston College

School of Theology and Ministry

\title{
Eucharistic Creation: Symbol, Meaning, Infinity
}

The precise nature of the encounter with the presence of Christ in the Eucharist has been expounded and explained variously by theologians over the past two millennia. Louis-Marie Chauvet in his watershed work Symbol and Sacrament proposes a postmodern account of being rooted in Eucharistic symbolic exchange. Drawing on Heidegger and Derrida, Chauvet criticizes onto-theological models which detail the Eucharist in metaphysical terms. Chauvet offers instead a view of being as mediate, locating the real not "behind" or "underneath" the symbolic, but precisely in the sign-ificant language of the symbolic order. ${ }^{1}$ Of this order the Eucharist is the prime image. However, some have pointed to weaknesses in Chauvet's argument inherited from his philosophical sources. ${ }^{2}$ Many of these can be bolstered by approaching the Eucharist from a theological-aesthetic perspective. This paper will examine possible contributions to Chauvet's Eucharistic theology by drawing on David Bentley Hart's aesthetic work The Beauty of the Infinite: The Aesthetics of Christian Truth. Beginning with the analogia entis (analogy of being), Hart proceeds to explain creation in terms of analogia delectationis (analogy of delight), and finally of analogia verbi (analogy of the word). This provides a basis for understanding all of creation Eucharistically: the mirror of being is the Sacrament itself. Thus "creation" describes not simply a former event at the beginning of time, but a particular relation to the Creator.

Chauvet, with Heidegger, questions the possibility of immediate access to the truth of being, calling for an honest recognition of human thrownness into the interpretive world of

\footnotetext{
${ }^{1}$ Louis-Marie Chauvet, Symbol and Sacrament: A Sacramental Reinterpretation of Christian Experience, trans. Patrick Madigan, S.J., and Madeleine Beaumont (Collegeville: The Liturgical Press, 1995), 274.

${ }^{2}$ Joseph C. Mudd, Eucharist as Meaning (Collegeville: Liturgical Press, 2014), 13.
} 
language and symbol. The sacraments, in Chauvet's view, are a call to renounce the "see-touchfind" pursuit of object-ivity and to affirm the ontological truth of the symbolic order. ${ }^{3}$ This symbolic order is outside the realm of value, and implicates humankind in a gracious gift/returngift relationship with God, realized in the sacraments. Christian identity itself, for Chauvet, is located in the tripartite relation of Sacrament-Scriptures-Ethics whereby the Church mediates Christ to the world. His discussion of being (symbol) and knowing (meaning), however, is complemented by the aesthetic voice: Beauty (infinity).

The Beauty of the Infinite is an attempt to retrieve aesthetic truth through a survey of the Trinity. If humans experience being mediately, beauty is perhaps the most vital and unique form of mediation. Scarcely anything holds such a purchase on human consciousness as does the beautiful. For Hart, beauty is objective, ${ }^{4}$ authoritative, ${ }^{5}$ and evocative; ${ }^{6}$ it is the true form of distance, respecting no boundary and transcending every division. ${ }^{7}$ Crucially, Hart claims that the beautiful inherently resists reduction to the merely symbolic. Hart would support Chauvet's criticism of the "onto-theo-logic" which attempts to arrest aesthetic truth on the surface in search of some other, undisclosed "depth" of authenticity. "In the moment of the beautiful," Hart writes, "one need attend only to the glory that it openly proclaims, and resist the temptation to seek out some gnosis secretly imparted." ${ }^{8}$ Symbolic beauty defies abstraction from its contexts, lest it be

\footnotetext{
${ }^{3}$ Chauvet, 106.

${ }^{4}$ David Bentley Hart, The Beauty of the Infinite: The Aesthetics of Christian Truth (Grand Rapids: Eerdmans Publishing Company, 2003), 17.

${ }^{5}$ Ibid., 21. Beauty is authoritative in theology in two aspects: It "shows creation to be the real theater of divine glory" and, on the other hand, "shows the world to be unnecessary, an expression of divine glory that is free, framed for God's pleasure."

${ }^{6}$ Ibid., 19. The appropriate desire evoked by true beauty is "not a coarse, impoverished desire to consume and dispose, but a desire made full at a distance, dwelling alongside what is loved and possessed in the intimacy of dispossession."

${ }^{7}$ Particularly, Hart notes, the division between transcendence and immanence. [FRAGMENT]

${ }^{8}$ Ibid., 25.
} 
rendered 'impotent, frozen in a great sea of 'meaningfulness', drifting endlessly toward ideality."9

With the path for an aesthetic sacramental theology thus opened, Hart plots a course through Trinitarian theology to creation through the analogia entis, which promises to elucidate Eucharistic communion. A Christian appreciation of being as beautiful is, Hart finds, modeled on the Trinitarian perichoresis. It is from this eternal dance of love that creation originates and of which creation is an aesthetic reflection. The dance is both limitless and perfect, lacking nothing: Each person of the Trinity is "infinitely determined as the living love of the divine persons ... to which infinity no moment of the negative or of becoming or even of 'triumph' can give increase." $" 10$ The Trinitarian God is not a formless ideal or abstraction. Indeed, the divine perichoresis is a concrete relation; it is the substantial formosus of God's fullness of form founded in the dynamism of Trinitarian life.

Creation is, then, an expression of grace. It is a "shining fabric of glory, whose inmost truth is its aesthetic correspondence to the beauty of divine love, as it is eternally expressed by the Trinity: A sacramental order of light." 11 As such, being represents an analogy of the divine beauty, an analogia delectationis. God saw all that He had made, and it was very good (Gen. 1:31). Hart takes this to be first and foremost an aesthetic affirmation, noting that moral evaluation only becomes necessary with the intrusion of $\sin .^{12}$ Creation is the overflowing gift of the perichoretic dance within God's being.

Chauvet follows Derrida in claiming that the gift of being involves one in a symbolic exchange which necessarily obliges the recipient to make a return-gift. This return-gift is no

\footnotetext{
${ }^{9}$ Ibid., 28.

${ }^{10}$ Hart, 167.

${ }^{11}$ Ibid., 252., emphasis added.

12 Ibid., 253.
} 
more and no less than eucharisteia, the giving of thanks. ${ }^{13}$ The idea is attractive prima facie, but Hart would be skeptical. He would object that this economy of power and debt unduly purges the gift-giving process of honest desire for the other. ${ }^{14}$ When agape is severed from eros, the former is reduced to a "sterile, almost suicidal expenditure of love," only superficially distinguishable from indifference or hatred. ${ }^{15}$ Gifts given in love express desire for the other, not as an indiscriminate wave of generalized givenness, but as a love that knows and calls the other by name. If the gift is not a sign of interest in the particular, it is only a dominating avalanche of indebtedness. On this point, Hart's description seems to harmonize more easily with a eucharistic view of being: We are called to, rather than implicated-in, the supper of the Lamb.

Chauvet would agree, however, that creation is language: a true symbol. However, being does not speak or point to a hidden reality beyond itself; it sings the doxology of the Creator's beauty. It is the analogia verbi, declaring distance without alienation through the aesthetic. In God, difference ${ }^{16}$ is neither flattened into shapeless conformity with a divine ideal, nor stratified in a hierarchical striving towards a Monad. Difference in God becomes a chorus of particularity giving voice to unique attestations of God's glory. Being's "correspondence" to God is one of deliberate variance, revealed in the form of utter joy. ${ }^{17}$ This rightly elicits a relationship of desire, but it is neither the desire of grasping domination nor desire in the Heideggerian sense: a reaching in futility towards an ever retreating presence-in-absence. Rather, felicity in God is

\footnotetext{
${ }^{13}$ Chauvet, 428-430.

${ }^{14}$ Hart, 262.

15 Ibid., 264.

${ }^{16}$ Hart, 194. Difference must not be conceived as some distance, as if there were some imaginary "space" separating God and creation. Indeed, one of Hart's central points is that God is that difference. The finite belongs to the infinite and never the reverse.

${ }^{17}$ Ibid., 181.
} 
found in the very epektasis of dispossession, which is content in endlessness: "The soul experiences ceaseless delight precisely in that its desire can know no final satiety."18

From this aesthetic perspective, it becomes clear why authentic symbols like the Eucharist are not to be searched out, mastered, or dredged for a deeper truth. The Eucharist is "surface," the pinnacle of Christ's beauty recapitulated, mediated, and, of course, really present. His presence is not merely static, like that of a corpse, but active, truly the Son of the Living God. Jesus, as the Christ, is not simply a symbol or messenger of God, but God Himself. ${ }^{19} \mathrm{He}$ is the concrete Redeemer, who saves by His very particularity. Both in the scandal of the cross and the glory of the resurrection, it is His real, "historical" beauty which draws all humanity to Him. He gives form to shapelessness, and it is this reality which is made present symbolically and aesthetically in Holy Communion.

The body, true bread, resists "scientific" (that is, analytic) discovery. No one takes the life of the Son from Him; He lays it down willingly. There is no esse to be uncovered, but an adesse, a being for, a fullness of presence as the head is present to the body. Reifying "Necrotic Temptations" ${ }^{\prime 20}$ of this presence may be, as Chauvet warns, easier to comprehend, but they are not the Risen Lord. Accepting symbolic mediation as aesthetic truth is precisely the surrender of a see-touch-find mentality - which is really nothing more than a foot-stamping demand that God meet one here and in this way - and a giving-up of finding Jesus as an already-out-there-now. ${ }^{21}$ And why shouldn't it be? Why look for the living among the dead? The blood, true drink, does not flood creation in an endless sea of obligation, but writes a new covenant. He is not crucified

\footnotetext{
${ }^{18}$ Ibid., 195.

${ }^{19}$ See Hart, 320.

${ }^{20}$ Chauvet, 261.

${ }^{21}$ Bernard Lonergan, "The Subject," quoted in Joseph C. Mudd, Eucharist as Meaning (Collegeville: Liturgical Press, 2014), 44.
} 
in the Eucharist afresh, but always offers Himself as gift-ever-given, desiring not the other "in general," but "you" in particular. Christ is poured out for you and for many.

But the abasement of Christ is one with His exaltation. The crucifixion and resurrection are not two dialectical "events," as if the latter were a sort of divine contingency plan. $M \bar{e}$ geneto! The ever-spoken Word goes forth and returns because going-forth is already who He is in God, and because all return is already accomplished in the Infinite One, who is Alpha and Omega. Hart explains:

The form of Christ inhabits at once a province of shadows and a region of glorious light, he is at once nocturnally and diurnally beautiful, his is simultaneously a way of abasement and a way of exaltation. And these two ways are one: Not a before and after, but a venturing forth from and return to the Father that is one motion, one life, one dramatic action that overcomes totality's defining horizon - death - not through reconciliation with the limits it marks but through an infinite act of kenosis and glorification that transgresses it [death], passes it by as if it were nothing. ${ }^{22}$

Thus participation in the Eucharist is to enter into the unimpeachable beauty of the Risen Lord, undefiled and untouched even by death. It is this mediation which is known and assented to not empirically, but on the level of judgment (faith). When in Eucharistic sharing Christ becomes more than simple datum and is realized as true donum, ${ }^{23}$ gift in the breaking of bread, the faithful may join in the acclamation of recognition: "My Lord and my God!"

Finally, it must be remembered that the Church looks ever forward in eschatological hope. Even while acknowledging communion through real presence and symbolic truth, it must be confessed that all creation groans for the day of its redemption. ${ }^{24}$ The beauty of being testifies to future hope of the Beatific Vision: "For now we see through a glass, darkly; but then face to face: now I know in part; but then I shall know fully even as I am known. ${ }^{, 25}$ Crucially, the

\footnotetext{
${ }^{22}$ Hart, 322.

${ }^{23}$ Hart, 333.

${ }^{24}$ Rom. 8:22. [VERSION]

${ }^{25} 1$ Cor. 13:12.
} 
symbolic order is not the obscuring glass through which one must peer, but the very reality seen. The symbolic is the real. It is the aesthetic surface in which God reveals Himself, the harmonious chorus mediating divine revelation. Neither is there need to bemoan this mediacy, gazing to the heavens as towards some distant, long-lost koinonia of immediate access to God. "Why do you stand here looking into the sky? This same Jesus, who has been taken from you into Heaven, will come back in the same way you have seen Him go. ${ }^{.26}$ Renunciation of the search for immediacy looks forward in hope to the day when faith becomes sight, as all creatures behold their God and King. It is this for which we eucharisto, for which we give thanks.

Creation is a eucharistic relation, an analogy mediated through the symbolic-aesthetic, awaiting final reconciliation with infinity.

${ }^{26}$ Acts 1:11. 


\section{Bibliography}

Chauvet, Louis-Marie. Symbol and Sacrament: A Sacramental Reinterpretation of Christian Experience. (Collegeville: The Liturgical Press, 1995).

Hart, David Bentley. The Beauty of the Infinite: The Aesthetics of Christian Truth. (Grand Rapids: Eerdmans Publishing Company, 2003).

Mudd, Joseph C. The Eucharist as Meaning. (Collegeville: The Liturgical Press, 2014). 